\title{
ROLL OF INFORMATION PROFESSIONALS IN THE CHANGING NEW ERA
}

\author{
Ashoka B L \\ Senior Scale Librarian \\ SB Government First Grade College, Mayakonda, Karnataka 577534 \\ E-mail: achhu.ashoka@gmail.com
}

\section{Manuscript Info}

\section{Manuscript History}

Received: 01 November 2020

Final Accepted: 22 December 2020

Published: 10 January 2021

Online Published: February 2021

DOI: http://dx.doi.org/10.35337/EIJLITR.2021.1201

Corresponding Author E-mail: achhu.ashoka@gmail.com (ASHOKA B L )

(C) ASHOKA B L The Author. This is an open access article under the terms of the Creative Commons Attribution License 4.0, which allows use, distribution and reproduction in any medium, provided the original work is properly cited.

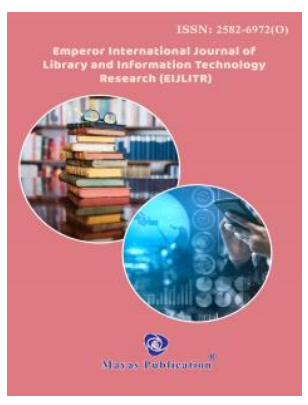

\section{Abstract}

Change and adaptability are the indications of nature. Twenty first century has changed the entire circumstance of information science. This is an electronic time. IT change has changed over information into power. As every general nation is logically getting globalized, capacities and consolidated dominating of its workforce has become genuine assets. This paper explains the work of information specialists in the present progressed age. Today in the modernized age, accountants can now don't be fundamentally information providers or the 'specialists of data'.

Keywords: Role, Information Professionals, Digital age.

\section{INTRODUCTION}

Information is the consequence of human cerebrum, all things considered. It may be dynamic or concrete. It doesn't exist for the prosperity of its own. It is for use. To ensure its most outrageous use it is to be passed on and shared. So correspondence is the key property of information. The target of information resources is improvement of data, limit, capacities, and potential outcomes of customer neighborhood. Every affiliation expects that their agents community and produce their best show recollecting the greater progressive targets.

\section{Libraries}

Today's libraries are not conventional. They are ending up being virtual libraries. They are for the most part available on automated construction and they appear to be like a PC place. They are empowering the composing based society to data based society. Impact of web and WWW(store spot of information) has 
extended the open possibilities and options in contrast to the libraries. In our regular libraries there are specific, social, authentic and monetary normal factors that structure an obviously multifaceted course of action of cutoff points to the domain where libraries work.

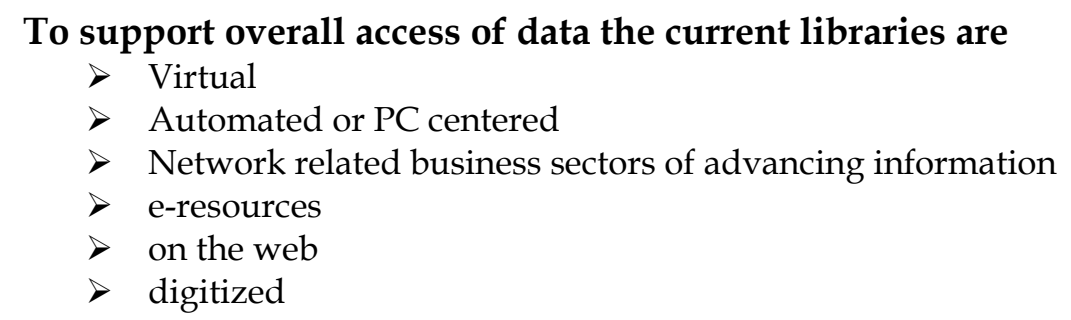

Current instruments in the libraries have offered absolute present day help to the customers. IT based guidance, autonomy permitted to educational establishments, participation with new universities all these are changing the novel circumstance and purpose behind school and school libraries in India. Libraries are ending up being media focal points of information resources. Web tending to, brought into the world progressed and changed over automated records are seeking after the substance of stack rooms and getting districts.

Growing assortments of handling and media transmission progresses are emerging to set out new open entryways for the improvement of information gathering, accumulating, recuperation, and movement. In the current circumstance there is still better speculation of the library where these five clear principles rely upon interfacing people, libraries and the information they use. Crawford and Gorman (1995) offered 'Five New Laws of Library Science' in the longing for modifying Ranganathan for the current libraries and their conceivable future:

$>$ Libraries serve mankind.

$>$ Respect all constructions by which data is passed on.

$>$ Use advancement distinctly to update organization.

$>$ Protect free permission to data.

$>$ Honor the past and make what's to come.

\section{Library Professionals}

For a library capable it isn't scarcely enough to be significantly qualified educational custodian. These days there is an interest for a caretaker having multidimensional wellness by and large districts like particular taking care of work, administrative work and library customer organizations with milder social relationship building capacities.

\section{Role of Library Professionals in Building Infrastructural Facilities in their Libraries}

Procurement of Library Software: There are diverse library virtual items for data section and substance the board in libraries. Eg. D-space., Greenstone, Fedora, E-Prints, etc Library writing computer programs is an onetime purchase and it is the central prerequisite for robotization in the libraries. Overseer's expect a critical part in picking the altered programming which is ensured for future overhauls. The inventive types of MS Windows/Linux based writing computer programs are having their individual advantages. They are orchestrated by the essential of the specific libraries needs and steady for future progressions of libraries. Manager should think about this. Accepting a contemporary advancement is a broad point. In a consistently changing development it is the commitment of the overseer to think about the versatility of the item to their libraries. ie, Choosing incredible programming for at whatever point wherever accessibility of information.

Retrospective Conversion: Librarian accept a fundamental and pressing part during the audit change of his library resources. Since rethinking for the modified programming do give suitable confirmation yet can't be checked. The likeness of one programming to another movements a ton with different features and setups. The need of the extraordinary master capacities are highlighted in keeping up their specific libraries resources. 
Electronic Resources: E-resources are automated changed over books and other getting materials. ELearning is dynamic, shared, sweeping, research masterminded smart learning in short time period, while customary libraries miss the mark on this office. Nevertheless, Digital libraries are facing the challenges like

$>$ Digital shielding

> Copyright and approving

$>$ Metadata creation

$>$ Compatibility of programming

Library capable by invigorating his particular data and by keeping awake with competition can handle or manage these issues viably. Guardian's work is essential and genuine.

\section{Need for NAAC Agency}

Public Assessment and Accreditation Council, a self-overseeing assortment of UGC is responsible for institutional accreditation and sees the working and assessment of library as a central part and vital sub unit in ensuring quality in high level training. To fulfill the NAAC necessities overseer needs to work as a pioneer in his library.

$>$ His drive capacities consolidates

$>$ Specific capacities

$>$ HRM capacities

$>$ Sensible capacities

$>$ Singular capacities

\section{Technical Skills are}

$>$ The ability to use fitting gadgets and strategies

$>$ Ability to explore new progressions

$>$ Knowledge of information sources and organizations

$>$ obligation of durable learning

$>$ keen limit

$>$ abilities in explicit zone

\section{HRM Skills}

HRM refer to behavioral skills of being able to work effectively with and through people in an organization.

\section{HRM skills are}

$>$ being able to work with people

$>$ ability to work effectively with subordinates

$>$ assist group members to achieve common goal in an organization

$>$ empathy and objectivity

\section{Conceptual Skills}

$>$ ability to work with ideas

$>$ understanding organizations behavior

$>$ to know the financial status of library

$>$ to understand the users demand

$>$ work with abstraction and hypothetical notion

\section{Personal Skills}

$>$ Intelligence

$>$ Emotional Maturity

$>$ Personal Motivation 
$>$ Integrity

$>$ Flexibility of Mind

A good digital library needs an efficient librarian. To perform efficient role a professional librarian needs personal attributes like

$>$ Intelligence

$>$ broad social outlook

$>$ decisiveness

$>$ experience and training

$>$ communication skills

$>$ educational skills

$>$ professional attitude

$>$ executing skills

$>$ human skills

$>$ In-depth technical skills

$>$ sincerity and patience

$>$ deep knowledge of the subjects

$>$ clear information

$>$ individual assistance

$>$ enthusiasm

$>$ sense of humor

$>$ willingness to the profession

$>$ pleasing personality

$>$ writing skills

$>$ teaching skills

$>$ social skills

$>$ Time management skills

$>$ With all these characters and attributes his role is

$>$ Information scientist

$>$ Generalist

$>$ Adviser and trainee

$>$ Humane

$>$ Gate keeper

> Gate opener

Efficiency and effectiveness are necessary for the growth and survival of library. Librarian's role to motivate the users towards goal achievement, to make them productive and goal oriented, make the libraries dynamic and vibrant is very important.

The knowledge bank gets renewed and enriched with use by knowledge workers. Improving organization productivity as well as improving employee productivity are wider challenges. Library users are our great resources. They must be encouraged to give the best to the institution.

\section{CONCLUSION}

Content management is a governing philosophy for gaining control over the flood of information. The electronic era is an opportunity to evaluate the resources of the library. Online environment is exploiting all types of communication tecchnologies for the user community. So library professionals play a crucial role in managing their libraries and users. 


\section{REFERENCE}

1. Knowledge Management/ by Rathan Reddy/ Himalaya Publilshing house Bengaluru/2011

2. Electronic journal of Academic and special librarianship, V.10, N.3 (winter 2009)

3. Arizona.openrepository.com

4. Crl.du.ac.in

5. WIKIPEDIA, The free encyclopedia, Wiki conference India, 2011.

6. Personality development and communication skills/ by Pushpa Ranganath/ Himalaya Publishing house/ Bengaluru/ 2008.

7. Organizational Behavior/ by Hiriyappa/ New Age International Publisher, Bengaluru/ 2009.

8. Advanced Methods of Teaching/ by T. Pradeep Kumar/ Himalaya Publishing House, Bengaluru, 2012.

9. Human Resource Management/ by Shashi K. Gupta and Rosy Joshi/ Kalyani Publishers, New Delhi, 2009.

10. Digital futures: strategies for the information age/ by Marilyn

11. Deegan and Simon Tanner/ Library Association Publishing, London, /2002. 